\title{
Genetic divergence based on leaf vegetative and anatomical traits of Coffea canephora clones
}

\section{Divergência genética com base em características vegetativas e anatômicas foliares de clones de Coffea canephora}

\author{
Larissa Fatarelli Bento de Araújo ${ }^{1 * ;}$ : Marcelo Curitiba Espindula2; \\ Rodrigo Barros Rocha2; Josemar Dávila Torres;; Marcela Campanharo4; \\ Wesley Franco Oliveira Pego ${ }^{5}$; Samuel Elias de Souza Rosa ${ }^{5}$
}

\section{Highlights}

Changes in leaf anatomy are associated with drought tolerance.

Anatomical characteristics as a new tool to identify genetic divergence.

Anatomical characteristics identify early drought-tolerant genotypes.

\begin{abstract}
Knowledge of the expression of traits associated with drought tolerance is important to mitigate impacts on coffee production in a climate change scenario. This study aimed to understand the genetic divergence between Coffea canephora genotypes grown in the Western Amazon based on leaf vegetative and anatomical traits. For this, fifteen high-performance genotypes were evaluated in a randomized block design with five replications of one plant per plot to analyze three leaf vegetative traits (leaf area index, root volume, and total dry mass) and five leaf anatomical traits (polar and equatorial diameter, density and number of stomata, and stomatal area). The data were interpreted using analysis of variance and the Scott-Knott mean cluster test ( $p \leq 0.05)$. The Tocher optimization method and principal component analysis with reference points were used to quantify the genetic divergence. Tocher clustering separated the fifteen clones into five groups, and the scatter in the plane into three groups. Stomatal density was the trait that most contributed to the dissimilarity between genotypes with the potential to be used in future studies for the selection of water deficit-tolerant genotypes. The BRS 3213 genotype showed the greatest

1 Profa Dra, Postgraduate Program in Environmental Science, Fundação Universidade Federal de Rondônia, UNIR, Rolim de Moura, RO, Brazil. E-mail: larissafatarelli@gmail.com

2 Researcher, Empresa Brasileira de Pesquisa Agropecuária, EMBRAPA Rondônia, Porto Velho, RO, Brazil. E-mail: marcelo.espindula@embrapa.br; rodrigo.rocha@embrapa.br

${ }^{3}$ Master in Environmental Science, UNIR, Rolim de Moura, RO, Brazil. E-mail: josemar-torres@hotmail.com

${ }^{4}$ Profa Dra, Course in Biology, UNIR, Porto Velho, RO. Brazil. E-mail: marcela.campanharo@unir.br

${ }^{5}$ Undergraduate Students in Biology, UNIR, Porto Velho, RO, Brasil. E-mail: wesleyfranco_pvh@hotmail.com; souzasamu18@gmail.com

* Author for correspondence
\end{abstract}

Received: Oct. 27, 2020 - Approved: June 10, 2021 
genetic dissimilarity and composed a group isolated from the other genotypes in terms of anatomical characteristics. Hybrids 12 and 15 have leaf anatomical traits with higher drought tolerance potential.

Key words: Tolerance. Leaf anatomy. Stomatal density. Drought resistance.

\section{Resumo}

O conhecimento da expressão de características associadas a tolerância a seca é importante para mitigar os impactos na produção cafeeira em um cenário de mudanças climáticas. Objetivou-se com o presente trabalho entender a divergência de natureza genética entre genótipos de Coffea canephora cultivados na Amazônia Ocidental, com base em características vegetativas e anatômicas foliares. Para isso, quinze genótipos foram avaliados em delineamento de blocos casualizados com cinco repetições de uma planta por parcela, para análise de três características vegetativas (área foliar, volume de raiz, massa seca total) e cinco características anatômicas foliares (diâmetro polar e equatorial; densidade e número de estômatos e área estomática). Os dados foram interpretados utilizando análise de variância e o teste de Scott-Knott $(p \leq 0,05)$. Para quantificar a divergência genética foi interpretado o agrupamento estimado pelo método de otimização de Tocher e a dispersão no plano obtida utilizando a técnica de componentes principais. $\mathrm{O}$ agrupamento de Tocher separou os 15 clones em cinco grupos, e a dispersão no plano em três grupos. A densidade estomática foi a característica que mais contribuiu para a dissimilaridade entre os genótipos com potencial para ser utilizada em estudos futuros de seleção de genótipos tolerantes ao déficit hídrico. O genótipo BRS 3213 apresentou maior dissimilaridade genética, constituindo um grupo isolado dos demais genótipos quanto as características anatômicas. Os Híbridos 12 e 15 apresentam características anatômicas foliares com maior potencial de tolerância a seca.

Palavras-chave: Tolerância. Déficit hídrico. Anatomia foliar. Densidade de estômatos.

\section{Introduction}

Coffee is commercially produced from the cultivation of two species: Coffea arabica L. and Coffea canephora Pierre ex A. Froehner (International Coffee Organization [ICO], 2019). Despite the higher adaptability of Coffea canephora to tropical regions (high temperatures and low altitude), modeling studies point to considerable reductions in areas suitable for coffee production due to the climate change effects (Bunn, Laderach, Rivera, \& Kirschke, 2015; Craparo, Van Asten, Läderach, Jassogne, \& Grab, 2015). An increase in global temperature is predicted among the effects, accompanied by changes in rainfall patterns and the frequency of prolonged episodes of drought (Intergovernmental Panel on Climate Change [IPCC], 2014).

Several studies have pointed to positive perspectives regarding $C$. arabica and $C$. canephora production on the increase in temperature and atmospheric $\mathrm{CO}_{2}$ (Martins et al., 2016; W. P. Rodrigues et al., 2016b, 2018; Scotti-Campos et al., 2019). However, the fundamental strategy regarding drought remains plant selection for the production of new water stress-tolerant cultivars (DaMatta, Avila, Cardoso, Martins, \& Ramalho, 2018). The long life cycle and productive bienniality of coffee make the development of new cultivars a process that takes several years, a worrying fact in a scenario of changes that are already underway. 
Drought tolerance has already been found in the species C. racemosa, arabica coffee with introgression by $C$. racemosa (Medina et al., 1977; Melo, Fernandes-Brum, Pereira, Castro, \& Chalfun, 2014; Carvalho et al., 2017), and wild arabica coffee from Ethiopia (Queiroz-Voltan, Nardin, Fazuoli, \& Braghini, 2014; Carvalho et al., 2017). Drought tolerance was also identified in some $C$. arabica with introgression by $C$. liberica, such as the coffee BA-10 and cultivar IPR 100 (Mazzafera \& Carvalho, 1987; Carvalho et al., 2017), and those with introgression by C. canephora, such as the cultivars IAPAR 59 (Freire, Marraccini, Rodrigues, \& Andrade, 2013; Carvalho et al., 2017), IPR 98, and IPR 103 (Carvalho et al., 2017).

Leaf anatomy studies associated with vegetative traits provide support for the identification of promising genotypes, considering early selection and the use of selectionindicesthatconsider the combination of various characteristics as selection criteria, seeking to identify genotypes that present a set of favorable characteristics (Gama, Sales, Castanheira, Silveira, \& Azevedo, 2017; Oliveira, Meyerb, Afonso, \& Gonçalves, 2018; Viana et al., 2018a,b; Locatelli et al., 2019).

In the case of drought tolerance, the association of leaf and anatomical traits has shown to be promising as criteria for the selection of $C$. arabica (Castanheira et al., 2016) and C. canephora (Giles et al., 2019) genotypes. The presence of a higher number of stomata, density, and change in the size of polar and equatorial diameters can provide plants with drought tolerance by contributing to an equilibrium between gas exchanges and allowing higher photosynthetic efficiency (L. A. Batista, Guimaraes, Pereira, Carvalho, \& Castro, 2010). Likewise, the polar diameter to equatorial diameter ratio determines stomatal functionality. In other words, high values for this ratio indicate that the stomata acquired a more ellipsoid shape (Castro, Pereira, \& Paiva, 2009). Thus, the more elliptical morphology of stomata provides less water loss to the environment (Castanheira et al., 2016) and, at the same time, enables $\mathrm{CO}_{2}$ capture.

In this scenario, methodologies based on principal components are used seeking to reduce the dimensionality of the original variables, representing the original variability in a scatter in the plane with few axes (Covre et al., 2016; W. P. Rodrigues, Vieira, Teodoro, Partelli, \& Barbosa, 2016a; Rodrigues, Brinate, Martins, Colodetti, \& Tomaz, 2017; Starling et al., 2019). Thus, this study aimed to quantify the genetic divergences between Coffea canephora genotypes based on leaf vegetative and anatomical traits to establish criteria for the early selection of water deficittolerant genotypes.

\section{Material and Methods}

\section{Experimental design}

The experiment was conducted in a greenhouse belonging to Embrapa Rondônia (longitude $8^{\circ} 48^{\prime} 15^{\prime \prime} \mathrm{S}$ and latitude 6351'5" W), located in the municipality of Porto Velho, RO, Brazil. The climate of the region is Am, that is, a tropical monsoon climate, according to the Köppen classification, with a rainy summer (October to May) and dry winter (June to September). The mean monthly temperatures range from $26^{\circ} \mathrm{C}$ in the summer to $24^{\circ} \mathrm{C}$ in the winter. The mean annual precipitation is 2.498 $\mathrm{mm}$ (Alvares, Stape, Sentelhas, Gonçalves, \& Sparovek, 2013). The data on maximum, mean, and minimum temperatures $\left({ }^{\circ} \mathrm{C}\right)$, relative 
humidity (\%), solar radiation ( $\left.\mathrm{KJ} \mathrm{m}^{-2}\right)$, and wind $\left(\mathrm{m} \mathrm{s}^{-1}\right)$ (Figure 1) throughout the experimental period (June to November 2017) were provided by the weather station of the Instituto Nacional de Meteorologia (INMET, 2020) headquartered at the Embrapa Rondônia experimental station.
Fifteen high-performance genotypes of C. canephora, belonging to the robusta and conilon botanical variety, were evaluated considering a completely randomized block design with five replications of one plant per plot.
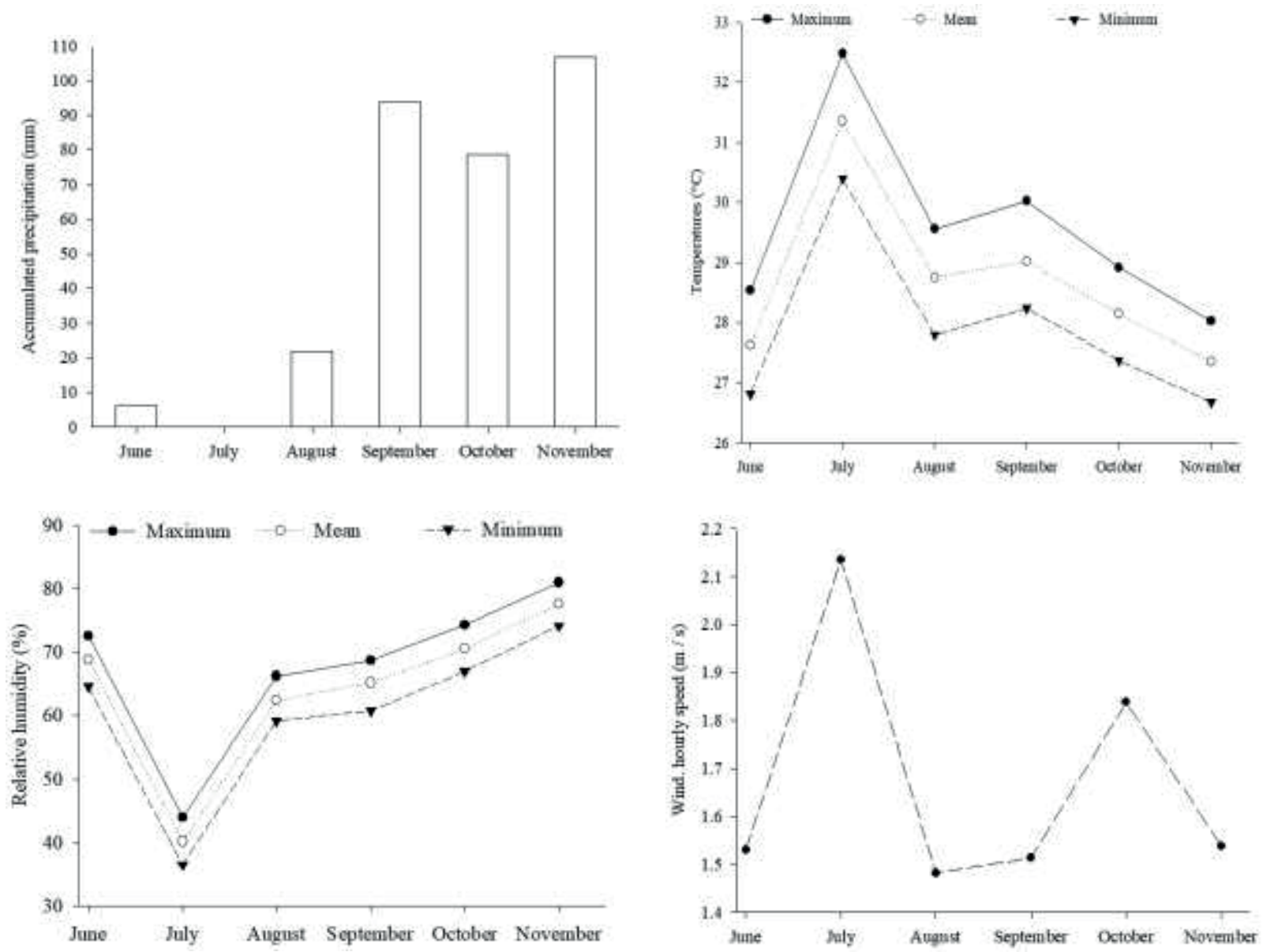

Figure 1. Accumulated precipitation (mm); Temperature $\left({ }^{\circ} \mathrm{C}\right)$; Relative humidity (\%); Wind, hourly speed ( $\left.\mathrm{m} \mathrm{s}^{-1}\right)$; June; July; August; September; October; November; Maximum; Mean; Minimum.

The C. canephora seedlings were maintained under greenhouse conditions using polyethylene containers with an 18- $\mathrm{dm}^{3}$ volumetric capacity filled with soil previously corrected for conilon and robusta coffee cultivation in the state of Rondônia, according to the recommendations of Espindula et al.
(2015) and nutritional requirements, according to the methodology proposed by Novais, Neves and Barros (1991).

Water replacement to $100 \%$ of the field capacity was carried out whenever the soil moisture reached $75 \%$, which was evaluated by the difference in pot mass. 


\section{Genetic material}

The genotypes were obtained from targeted hybridizations carried out in 2004 (Teixeira et al., 2017), followed by the evaluation of plants under experimental conditions in the period from 2005 to 2012 (Teixeira et al., 2017) and field evaluations in different environments of the Western Amazon carried out from 2013 to 2019 (Espindula et al., 2019). The genotypes identified by the prefix BRS were registered in the National Plant Variety Registry (RNC) of the Ministry of Agriculture, Food Supply and Livestock (MAPA) due to their superior productive potential and agronomic characteristics favorable to cultivation (Table 1) (Teixeira et al., 2020). The registered genotypes were named in this study identically to those registered in the RNC. Hybrids 9, 12, and 15 are from the Embrapa Rondônia germplasm bank.

\section{Evaluation of vegetative traits}

The following traits were evaluated after 150 days of growth in the greenhouse: root system volume $\left(\mathrm{cm}^{3}\right)$ in a container with known water volume; leaf area $\left(\mathrm{cm}^{2}\right)$, estimated non-destructively using linear models (Barros, Maestri, Vieira, \& Braga, 1973; Brinate et al., 2015); and biomass production (g plant $\left.{ }^{-1}\right)$, estimated from the mass of roots, stems, and leaves, which were dried in a forcedair ventilation oven at $65{ }^{\circ} \mathrm{C}$ until reaching a constant weight, determined on a precision analytical balance.

\section{Evaluations of leaf anatomy}

Six fully expanded leaves taken from the third node of plagiotropic branches from the apex to the base were used after 150 days of growth in a nursery. After collection, paradermal sections were obtained by means of impressions made by Super Bonder ${ }^{\circledR}$ adhesive using polished matte slides. Three slides were prepared per leaf and six fields were evaluated per slide using a 40x magnification objective lens. Subsequently, these slides were observed and photographed under an Olympus BX 41 optical microscope equipped with a digital camera. 
Table 1

List of genotypes, genealogy, and date of registration of Coffea canephora genotypes in the National Plant Variety Registry

\begin{tabular}{|cccc|}
\hline Genotype & Origin & Genealogy & Registry \\
\hline BRS - 1251 & Cultivar BRS Ouro Preto & Open pollination & 2013 \\
\hline BRS - 160 & Cultivar BRS Ouro Preto & Open pollination & 2013 \\
\hline BRS 12162 & Cultivar Robustas Amazônicos & Emcapa03xRobusta1675 & 2019 \\
\hline BRS 2299 & Cultivar Robustas Amazônicos & Open pollination & 2019 \\
\hline BRS 2314 & Cultivar Robustas Amazônicos & Emcapa03xRobusta640 & 2019 \\
BRS 2336 & Cultivar Robustas Amazônicos & Open pollination & 2019 \\
\hline BRS 2357 & Cultivar Robustas Amazônicos & Open pollination & 2019 \\
BRS 3137 & Cultivar Robustas Amazônicos & Open pollination & 2019 \\
\hline BRS 3193 & Cultivar Robustas Amazônicos & Open pollination & 2019 \\
\hline BRS 3210 & Cultivar Robustas Amazônicos & Emcapa03xRobusta2258 & 2019 \\
\hline BRS 3213 & Cultivar Robustas Amazônicos & Emcapa03xRobusta2258 & 2019 \\
BRS 3220 & Cultivar Robustas Amazônicos & Emcapa03xRobusta1675 & 2019 \\
\hline Hybrid 9 & Germplasm bank & Emcapa03xRobusta640 & Not registered \\
Hybrid 12 & Germplasm bank & Emcapa03xRobusta2258 & Not registered \\
\hline Hybrid 15 & Germplasm bank & Emcapa03xRobusta2258 & Not registered \\
\hline
\end{tabular}

${ }^{1}$ Genotypes BRS 125 and BRS 160 were registered together with 13 other genotypes to form the multi-clonal cultivar Conilon-BRS Ouro Preto (Ramalho, Rocha, Veneziano, \& Santos, 2014). ${ }^{2}$ The genotypes released in 2019 were registered individually as a monoclonal cultivar (Espindula et al., 2019).

The images were analyzed by the specific software for image analysis Q-Capture to obtain the evaluation of the following traits: number of stomata (NS), stomatal density (SD - number of stomata per unit area), polar diameter $(P D, \mu \mathrm{m})$, equatorial diameter (ED, $\mu \mathrm{m})$ (Castro et al., 2009), and stomatal area index (SAI = PD $\times$ ED) (Sack \& Buckley, 2016).

\section{Genetical diversity}

Estimates of the F-test of analysis of variance, the environmental coefficient of variation (CVe), and the genetic coefficient of variation $(\mathrm{CVg})$ and heritability (h) of the traits were considered. The means were grouped using the Scott-Knott test ( $\mathrm{p} \leq 0.05)$.
The Mahalanobis generalized distance was used to estimate the divergence between genotypes (Cruz \& Regazzi, 1997), and the Tocher algorithm (Rao, 1952 cited by Cruz \& Regazzi, 1997) was used for clustering with maximum variability between groups and minimum variation within groups. The principal component technique was used to reduce the dimensionality of the data to represent the genotypes in a scatter in the plane, associated with reference points that represent the maximum and minimum values of the evaluated traits (Cruz \& Regazzi, 1997; Rocha, Muro-Abad, Araujo, \& Cruz, 2005). Analyses were performed using the GENES software (Cruz, 2016). 


\section{Results and Discussion}

The genotypes showed significant differences $(p \leq 0.05)$ for all the evaluated anatomical and vegetative traits (Table 2). These results show the existence of genetic variability between C. canephora genotypes grown in Western Amazon. The characterization of genetic variability in the population is important because it allows its use in breeding programs (Nascimento, Gurgel, Bhering, \& Ribeiro, 2014; N. S. Oliveira et al., 2015), identifying genotypes that can be used for the selection of traits of interest within and out of populations (Giles et al., 2019).

\section{Table 2}

Summary of analysis of variance and genetic parameters of leaf and vegetative morpho-anatomical traits in Coffea canephora genotypes

\begin{tabular}{lcccccc} 
Trait & $\mathrm{F}$ & Mean & $\mathrm{CV}_{\mathrm{g}}$ & $\mathrm{CV}$ & $\mathrm{CV}_{\mathrm{g}} / \mathrm{CV}_{\mathrm{e}}$ & $\mathrm{h}^{2}$ \\
\hline Polar diameter & $4.50^{* *}$ & 22.54 & 6.15 & 8.05 & 0.76 & 77.79 \\
Equatorial diameter & $1.65^{*}$ & 12.63 & 2.99 & 9.08 & 0.33 & 39.52 \\
Stomatal area & $3.15^{* *}$ & 286.41 & 9.17 & 15.33 & 0.60 & 68.24 \\
Stomatal density & $9.12^{* *}$ & 20.01 & 15.18 & 13.05 & 1.16 & 89.03 \\
Total dry mass & $14.97^{* *}$ & 42.92 & 13.26 & 8.69 & 1.53 & 93.32 \\
Root system volume & $11.39^{* *}$ & 52.14 & 17.40 & 13.22 & 1.32 & 91.22 \\
Leaf area & $13.97^{* *}$ & 5635.79 & 11.29 & 7.68 & 1.47 & 92.84 \\
Number of stomata & $9.12^{* *}$ & 72.44 & 15.18 & 13.05 & 1.16 & 89.03
\end{tabular}

F: F statistic value calculated from the analysis of variance; CVg: genetic coefficient of variation; CVe: experimental coefficient of variation; CVg/CVe: genetic to experimental coefficient of variation ratio; h2: heritability. ${ }^{*} 5 \%$ significance; **1\% significance.

Estimates of experimental coefficient of variation (CVe) ranged from 7.68 to $15.33 \%$, indicating that some traits have a quantitative character, that is, they are more influenced by environmental effects. Only the stomatal area (15.33\%) presented environmental variance higher than genetic variance among the analyzed traits, unlike what was observed in another study (Giles et al., 2019).

Moreover, estimates of the genetic coefficient of variation $(\mathrm{CVg})$ ranged from 2.99 to $17.40 \%$, in which the root volume, number of stomata, and stomatal density presented the highest estimates, with values of $17.40,15.18$, and $15.18 \%$, respectively (Table 2 ). The genetic coefficient of variation $(\mathrm{CVg})$ is a relationship between the genetic standard deviation and the experimental mean, interpreted compared with the experimental coefficient of variation. Relationships between $\mathrm{CVg}$ and CVe close to or higher than the unity indicate a favorable condition for obtaining gains from plant selection, as they are more associated with the contribution of genetic components than with environmental variations (Nascimento et al., 2014; Rodrigues et al., 2017). This condition was observed for stomatal density, total dry mass, root system volume, leaf area, number of stomata, and polar diameter (Table 2). 
Estimates of heritability $\left(\mathrm{h}^{2}\right)$, which measures the relationship between genotypic and phenotypic variance, showed high values for almost all the evaluated traits, except for equatorial diameter $\left(h^{2}=39.52\right)$ (Nascimento et al., 2014; Rodrigues et al., 2017). These results reinforce the possibility of selecting superior genotypes with a higher degree of safety for the desired traits, as they represent less environmental interference on traits and higher participation of the genotype in total variability (N. S. Oliveira et al., 2015; Ferreira, Viana, Silva, Santos, \& Santos, 2016).

The Scott-Knott test evidenced differences between genotypes for the analyzed leaf anatomical and agronomic traits (Table 3). These phenotypic differences allowed grouping the genotypes into homogeneous groups according to their performance for each evaluated trait (Giles et al., 2019).

\section{Table 3}

\section{Leaf anatomical traits of 15 genotypes of Coffea canephora grown in Western Amazon}

\begin{tabular}{|c|c|c|c|c|c|}
\hline \multirow{2}{*}{ Genotype } & $\mathrm{PD}^{1}$ & $\mathrm{ED}^{1}$ & $\mathrm{AE}^{1}$ & $\mathrm{DE}^{1}$ & \multirow{2}{*}{$\mathrm{NE}^{1}$} \\
\hline & $\mu \mathrm{m}$ & $\mu \mathrm{m}$ & $\mu m^{2}$ & No. stomata $\mathrm{mm}^{-2}$ & \\
\hline BRS OPO 125 & $21.10 c$ & $11.96 b$ & $252.23 b$ & $22.70 b$ & $82.16 \mathrm{~b}$ \\
\hline BRS OPO 160 & $21.93 c$ & $13.15 a$ & $289.88 a$ & $16.78 \mathrm{c}$ & $60.83 c$ \\
\hline BRS 1216 & $21.41 \mathrm{c}$ & $12.05 b$ & $259.46 b$ & $20.06 b$ & $72.66 b$ \\
\hline BRS 2299 & $23.13 b$ & $12.40 \mathrm{~b}$ & $289.90 a$ & $23.00 \mathrm{~b}$ & $83.25 b$ \\
\hline BRS 2314 & $22.10 \mathrm{c}$ & $13.08 a$ & $290.21 a$ & $14.81 \mathrm{c}$ & $53.66 c$ \\
\hline BRS 2336 & $21.66 \mathrm{c}$ & $12.08 b$ & $262.78 b$ & $26.21 a$ & $95.00 a$ \\
\hline BRS 2357 & $21.78 \mathrm{c}$ & $12.35 b$ & $269.58 b$ & $19.33 c$ & $70.00 c$ \\
\hline BRS 3137 & $22.93 b$ & $12.60 \mathrm{~b}$ & $288.58 a$ & $15.91 \mathrm{c}$ & $57.66 \mathrm{c}$ \\
\hline BRS 3193 & $23.81 b$ & $13.08 a$ & $311.81 a$ & $22.18 b$ & $80.41 b$ \\
\hline BRS 3210 & $19.46 \mathrm{c}$ & $11.53 b$ & $224.88 b$ & $22.78 b$ & $82.50 b$ \\
\hline BRS 3213 & $26.31 a$ & $13.66 a$ & $360.55 a$ & $17.16 \mathrm{c}$ & $62.16 \mathrm{c}$ \\
\hline BRS 3220 & $23.43 b$ & $12.18 b$ & $285.28 a$ & $18.50 \mathrm{c}$ & $66.91 \mathrm{c}$ \\
\hline Hybrid 9 & $22.45 \mathrm{c}$ & $13.05 a$ & $292.65 a$ & $17.40 \mathrm{c}$ & $63.08 c$ \\
\hline Hybrid 12 & $22.45 c$ & $12.96 a$ & $295.50 a$ & $20.80 b$ & $75.33 b$ \\
\hline Hybrid 15 & $24.18 b$ & $13.28 a$ & $322.91 a$ & $22.35 b$ & $81.00 \mathrm{~b}$ \\
\hline
\end{tabular}

${ }^{1}$ Means followed by the same letters in the columns do not differ from each other by the Scott-Knott test $(p \leq 0.05)$. PD: polar diameter; ED: equatorial diameter; SA: stomatal area; SD: stomatal density; NS: number of stomata.

The stomatal density (SD) values ranged from 14.81 to 26.21 stomata $\mathrm{mm}^{-2}$ (Table 3). The variation in the number of stomata (NS) ranged from 53.66 to 95 . Both SD and NS resulted in the formation of three distinct groups composed of the same genotypes. A group with the lowest values represented by the genotypes BRS OPO 160, BRS 2314, BRS
2357, BRS 3137, BRS 3213, BRS 3220, and Hybrid 9, followed by an intermediate group consisting of the genotypes BRS OPO 125 , BRS 1216, BRS 2299, BRS 3193, BRS 3210 , Hybrid 12, and Hybrid 15, and a third group formed by the genotype BRS 2336, with higher stomatal density and number of stomata. 
One of the highest impediments for coffee production under water deficit conditions is precisely the drop in $\mathrm{CO} 2$ assimilation due to a reduction in stomatal conductance. This reduction in stomatal conductance occurs as a function of coffee sensitivity to soil water availability and air evaporation, which induce stomatal closure (K. D. Batista et al., 2012; Menezes-Silva et al., 2017). Therefore, genotypes such as BRS 2336, which have a higher density and number of stomata, may have higher photosynthetic efficiency under such conditions (Castro et al., 2009). It occurs because a higher stomatal density can prevent excessive transpiration during the time of stomatal opening and, at the same time, allow $\mathrm{CO}_{2}$ assimilation (L. A. Batista et al., 2010).

The polar diameter (PD) of stomata ranged from 19.46 to $26.31 \mu \mathrm{m}$, which allowed the formation of three groups in the following order relative to size: genotypes BRS OPO 125, BRS OPO 160, BRS 1216, BRS 2314, BRS 2336, BRS 2357, BRS 3210, Hybrid 9, and Hybrid 12, which presented the smallest polar diameters, followed by a group formed by the genotypes BRS 2299, BRS 3137, BRS 3193, BRS 3220, and Hybrid 15 and a group formed by the genotype BRS 3213, with the highest value observed for PD size. The values observed for equatorial diameter (ED) ranged from 11.53 to $13.66 \mu \mathrm{m}$, with the formation of only two groups. The genotypes BRS OPO 125, BRS 1216, BRS 2299, BRS 2336, BRS 2357, BRS 3137, BRS 3210, and BRS 3220, with the smallest sizes (Table 3), and the genotypes BRS OPO 160, BRS 2314, BRS 3193, BRS 3213, Hybrid 9, Hybrid 12, and Hybrid15 were grouped into a group with higher ED.

Polar and equatorial diameters are related to the efficiency of gas exchange ( $L$.
A. Batista et al., 2010). The polar to equatorial diameter ratio influences the stomatal functionality, that is, the stomatal shape. A higher stomatal functionality indicates that the stomata acquired a more ellipsoid shape (Castro et al., 2009). This more elliptical morphology provides less water loss to the environment (Castanheira et al, 2016) and, at the same time, enables $\mathrm{CO} 2$ capture. Thus, in environments with less water availability, the genotypes BRS 3193, BRS 3213, and Hybrid 15 would present an advantage relative to this stressful condition over the other evaluated genotypes.

The stomatal area (SA) ranged from 224.88 to $360.55 \mu^{2}$ (Table 3). This variability allowed the formation of two groups. Five genotypes (BRS OPO 125, BRS 1216, BRS 2336, BRS 2357, and BRS 3210) were included in the group with the lowest values of the stomatal area and ten genotypes (BRS OPO 160, BRS 2299, BRS 2314, BRS 3137, BRS 3193, BRS 3213, BRS 3220, Hybrid 9, Hybrid 12 , and Hybrid 15) were included in a group with the highest values for SA, all with values higher than $285 \mu \mathrm{m}^{2}$.

This genetic variability for anatomical traits among coffee genotypes detected by the Scott-Knott test has also been verified in studies with $C$. arabica. In these studies, a direct relationship was found with the physiology of plants and favorable conditions for studies of genetic divergence (Castanheira et al., 2016; Viana et al., 2018a).

The highest difference regarding vegetative traits was observed for total dry mass (TDM), with values ranging from 33.38 to $54.43 \mathrm{mg}$ (Table 4). This TDM variation allowed the formation of five distinct groups with the following increasing order of biomass 
accumulation: genotypes BRS OPO 160 and BRS 2357, followed by genotypes BRS OPO 121 and BRS 3137, genotypes BRS 2299, BRS 2314, BRS 2336, and BRS 3193, genotypes BRS 3210 and BRS 3220, and ending with the genotypes that presented the highest biomass accumulation, that is, BRS 1216 and Hybrid 12.

The root system volume (RV) ranged from 37.25 to $68.25 \mathrm{~cm}^{3}$, which allowed the formation of three groups. The lowest, intermediate, and highest values of root system volume were observed for genotypes BRS OPO 125 and BRS OPO 160 (Table 4), genotypes BRS 2299, BRS 2314, BRS 2336, BRS 2357, BRS 3137, BRS 3213, BRS 3220, and Hybrid 15, and genotypes BRS 1216, BRS 3193, BRS 3210, Hybrid 9, and Hybrid 12 , respectively. The genotypes with the highest development of the root system under water deficit situations would be able to better explore the soil profile in search of water since adaptation to water-restricted environments has been related to deep and vigorous root systems (Blum, 2005).

The values of leaf area ranged from 4774.85 to $6879.95 \mathrm{~cm}^{2}$ leaf $^{-1}$, which allowed the formation of three groups. The lowest, intermediate, and highest values of leaf area were observed for genotypes BRS OPO 125 , BRS OPO 160, BRS 2314, BRS 2336, BRS 2357, BRS 3193, BRS 3210, and BRS Hybrid 9, genotypes BRS 1216, BRS 3137, BRS 3213, and BRS 3220, and genotypes BRS 2299, Hybrid 12, and Hybrid 15, respectively.

Table 4

Vegetative traits of 15 genotypes of Coffea canephora grown in Western Amazon

\begin{tabular}{|cccc|}
\hline Genotype & TDM $^{1}$ & RV $^{1}$ & LA1 \\
\cline { 2 - 2 } 125 & $\mathrm{~g}$ & $\mathrm{~cm}^{3}$ & $\mathrm{~cm}^{2}$ plant $^{-1}$ \\
\hline BRS OPO 160 & $37.86 \mathrm{~d}$ & $37.25 \mathrm{c}$ & $5230.33 \mathrm{c}$ \\
\hline BRS 1216 & $33.38 \mathrm{e}$ & $39.50 \mathrm{c}$ & $4774.85 \mathrm{c}$ \\
\hline BRS 2299 & $51.91 \mathrm{a}$ & $65.31 \mathrm{a}$ & $5782.21 \mathrm{~b}$ \\
\hline BRS 2314 & $43.38 \mathrm{c}$ & $50.38 \mathrm{~b}$ & $6433.50 \mathrm{a}$ \\
\hline BRS 2336 & $42.55 \mathrm{c}$ & $53.58 \mathrm{~b}$ & $5049.95 \mathrm{c}$ \\
\hline BRS 2357 & $42.85 \mathrm{c}$ & $46.45 \mathrm{~b}$ & $5336.63 \mathrm{c}$ \\
\hline BRS 3137 & $34.50 \mathrm{e}$ & $46.00 \mathrm{~b}$ & $5145.53 \mathrm{c}$ \\
\hline BRS 3193 & $39.50 \mathrm{~d}$ & $44.98 \mathrm{~b}$ & $5963.43 \mathrm{~b}$ \\
\hline BRS 3210 & $41.03 \mathrm{c}$ & $60.11 \mathrm{a}$ & $4768.23 \mathrm{c}$ \\
\hline BRS 3213 & $45.81 \mathrm{~b}$ & $59.20 \mathrm{a}$ & $5138.68 \mathrm{c}$ \\
\hline BRS 3220 & $38.86 \mathrm{~d}$ & $49.80 \mathrm{~b}$ & $5899.36 \mathrm{~b}$ \\
\hline Hybrid 9 & $49.33 \mathrm{~b}$ & $46.4 \mathrm{~b}$ & $6137.00 \mathrm{~b}$ \\
\hline Hybrid 12 & $43.68 \mathrm{c}$ & $68.25 \mathrm{a}$ & $5434.18 \mathrm{c}$ \\
\hline Hybrid 15 & $54.43 \mathrm{a}$ & $64.96 \mathrm{a}$ & $6879.95 \mathrm{a}$ \\
\hline
\end{tabular}

${ }^{1}$ Means followed by the same letters in the columns do not differ from each other by the Scott-Knott test ( $\left.p \leq 0.05\right)$. TDM: total dry mass; RV: root system volume; LA: leaf area. 
Some studies carried out with $C$. arabica (Schmildt, Amaral, Santos, \& Schmildt 2015) and C. canephora (Dubberstein et al., 2021) have shown the importance of selecting genotypes with larger leaves in breeding programs, as it is an indication of the crop yield potential. In this case, genotypes with larger leaf areas have larger surfaces for the light interception, which can result in higher photosynthetic rates and carbohydrate availability (Partelli, Vieira, Detmann, \& Campostrini, 2006). However, genotype selection for water-restricted environments should not be based only on leaf area, as one of the observed behaviors is the reduction of this trait as a way to reduce water loss through transpiration and avoid oxidative damage.

Estimates of the relative contribution of anatomical and vegetative traits to genetic diversity ranged from 2.33 to $31.04 \%$ (Table 5). Stomatal density (31.4\%), number of stomata (25.6\%), and total dry mass (14.7\%) were the traits that contributed most to genetic diversity.

This information has great relevance for the selection of promising materials, as the higher stomatal frequency and density represent an important tolerance response to water deficit (I. Oliveira et al., 2018; Locatelli et al., 2019). It occurs because a higher stomatal density allows the stomatal opening in a period in which it is possible to capture $\mathrm{CO}_{2}$ and prevents excessive transpiration. Thus, the plant may show a higher efficiency in photosynthetic metabolism (L. A. Batista et al., 2010).

\section{Table 5}

Relative contribution of eight vegetative and anatomical traits to the genetic diversity of 15 genotypes of Coffea canephora grown in Western Amazon

\begin{tabular}{|cc|}
\hline Trait & Relative contribution (\%) \\
\hline Stomatal density & 31.4 \\
\hline Number of stomata & 25.6 \\
\hline Total dry mass & 14.8 \\
Stomatal area & 12.0 \\
Leaf area & 6.1 \\
\hline Polar diameter & 4.3 \\
Root volume & 3.5 \\
\hline Equatorial diameter & 2.3 \\
\hline
\end{tabular}

The Mahalanobis distance $\left(\mathrm{D}^{2}\right)$ was used as a measure of genetic dissimilarity and the Tocher optimization method for the clustering with minimum variability within groups and maximum variability between groups to group the genotypes based on the variability of all traits. These analyses allowed the association of the 15 genotypes of $C$. canephora into five distinct groups (Table 6), in which the genotypes BRS 3210, BRS 3213, Hybrid 12, and Hybrid 15, belonging to the same full-sib family, were located in different groups. 
Table 6

Grouping according to the Tocher method from the Mahalanobis distance matrix $\left(D^{2}\right)$ estimated from the evaluation of eight vegetative and anatomical traits of 15 genotypes of Coffea canephora grown in Western Amazon

\begin{tabular}{cccccc}
\hline Group & \multicolumn{5}{c}{ Genotype } \\
\hline I & BRS 2299 & Hybrid 15 & BRS 3220 & BRS 3193 & \\
II & Hybrid 9 & BRS 2314 & BRS 3137 & BRS OPO 160 & BRS 2357 \\
III & BRS 2336 & BRS OPO125 & BRS 3210 & & \\
IV & BRS 1216 & Hybrid 12 & & & \\
V & BRS 3213 & & & \\
\hline
\end{tabular}

Anatomical traits - PD: polar diameter $(\mu \mathrm{m})$; ED: equatorial diameter $(\mu \mathrm{m})$; SA: stomatal area $\left(\mu \mathrm{m}^{2}\right)$; SD: stomatal density (number of stomata $\mathrm{mm}^{-2}$ ); NE: number of stomata. Vegetative traits - TDM: total dry mass (g); RV: root volume; LA: leaf area $\left(\mathrm{cm}^{2}\right.$ leaf $\left.^{-1}\right)$.

The grouping of genotypes is based on higher similarity within groups and higher heterogeneity between groups. Hybridization of genotypes from different groups has a higher potential for producing breeding populations with a higher variability for these traits. The genotypes BRS OPO 125, BRS OPO 160, and BRS 2357, which have typical characteristics of the conilon botanical variety, were organized into groups that have lower values of the evaluated traits. In contrast, hybrid genotypes resulting from the hybridization between the conilon and robusta botanical varieties were organized into groups that present values higher than the mean of the evaluated traits.

In addition, this information is important, as it prevents genotypes that have the same pattern of genetic similarities, such as the group formed by genotypes BRS 2299, Hybrid 15, BRS 3220, and BRS 3193 (Table
6), from being selected in future crosses, thus restricting the genetic variability and reducing the genetic gains to be obtained with selection (Azevedo et al., 2013). Furthermore, the efficient choice of genotypes for perennial species such as coffee prevents the work carried out over the years from being harmed (Ferreira et al., 2016).

Moreover, as a way to compare the effectiveness of using the traits measured in this research to evaluate the genetic variability and, above all, its use as a criterion for early selection of materials aimed at drought tolerance, the genotypes were also classified into three classes according to their performance. The principal component technique was used to obtain a scatter in the plane, which represents the grouping of $C$. canephora genotypes relative to the minimum, mean, and maximum performance of the traits (Figure 2). 


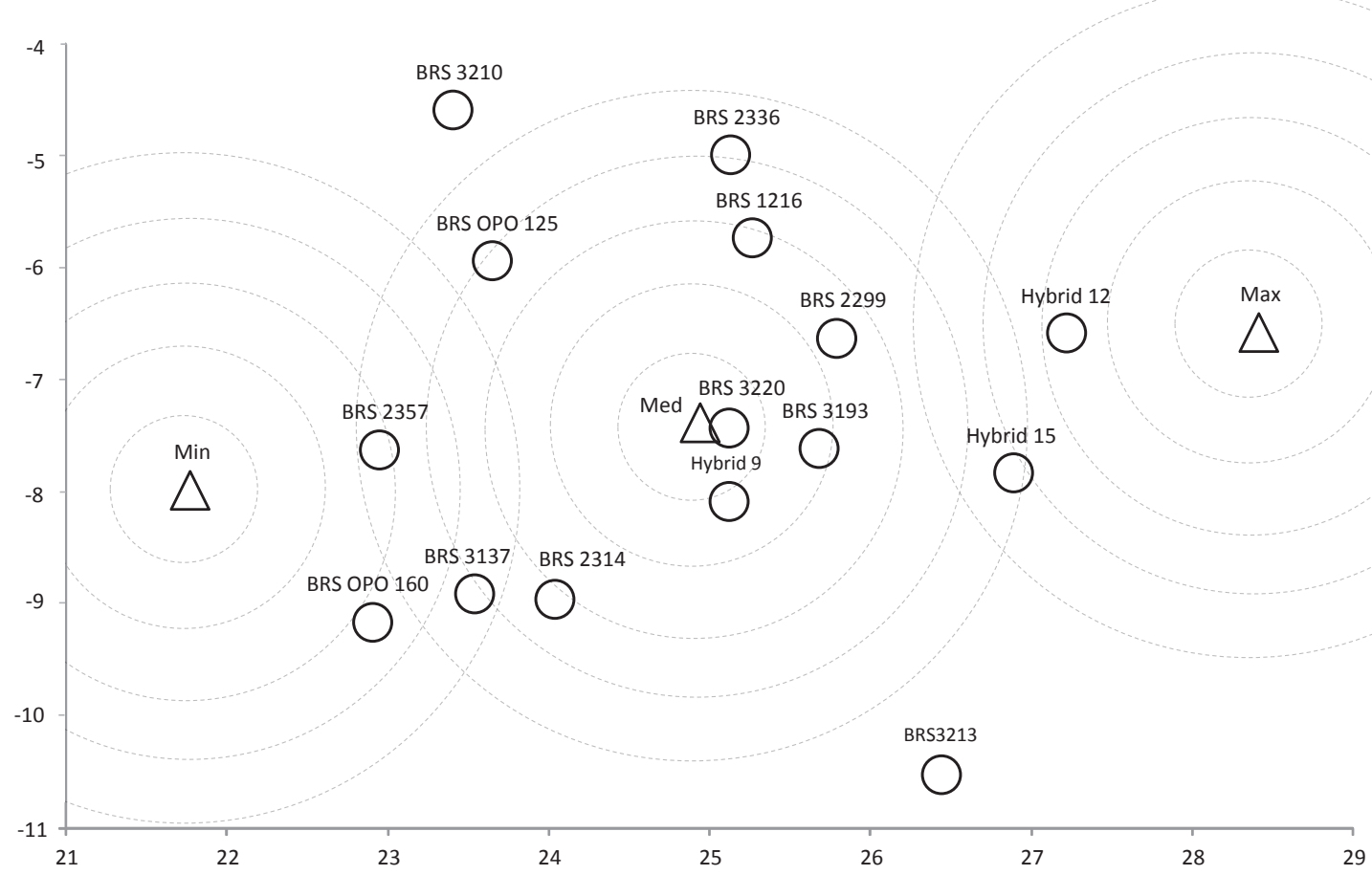

Figure 2. Scatter in the plane of measured variability in eight morphological and anatomical traits of 15 genotypes of Coffea canephora grown in Western Amazon. Points identified by a triangle represent ideal references, which present minimum (Min), median (Med), and maximum (Max) values for the evaluated traits.

Hybrids 12 and 15 were grouped within the maximum classification reference because they presented higher values for the evaluated vegetative and anatomical traits (Figure 1), being also classified into different groups by the Tocher method (Table 5). The second and largest group consisted of genotypes BRS 3220, BRS 3193, BRS 2299, BRS 2314, BRS 3137, BRS 1216, BRS 2336, Hybrid 9, and BRS(OP)125, being classified within the reference with an intermediate classification. A third group was formed by genotypes BRS 2357 and BRS(OP) 160, as they were classified within the reference with lower values of traits. The genotypes BRS 3213 and BRS 3210 did not group close to any reference because they presented high values for certain traits and low values for others.
Notably, studies have pointed out the importance of using different methodologies to evaluate genetic variability aiming to ensure higher reliability of results (Azevedo et al., 2013, 2015) and consistency in the clustering pattern (Nascimento et al., 2014). In fact, this criterion has been observed in studies aimed at characterizing the genetic variability among coffee genotypes to select superior materials for desired traits (Covre et al., 2016; W. N. Rodrigues et al., 2017; Starling et al., 2019; Giles et al., 2019).

Considering the selection aiming at drought tolerance, genotypes BRS 3213 and BRS 3210 have coffee traits more sensitive to the negative effects of water stress. On the other hand, genotypes Hybrid 12 and Hybrid 
15 indicate a better gas exchange response under a stressful drought condition, as they present higher stomatal frequency and density. It occurs because a higher stomatal density and number of stomata would maintain an efficient photosynthetic metabolism due to the maintenance of an adequate $\mathrm{CO}_{2}$ supply (L. A. Batista et al., 2010; Melo et al., 2014). However, the water vapor efflux and $\mathrm{CO}_{2}$ influx share the same path through the stomatal pores on leaf surfaces (Martins et al., 2016). This condition could compromise the photosynthetic efficiency of Hybrid 12 and Hybrid 15 if these genotypes did not present higher stomatal functionality.

Thus, we can state that the measured traits were promising for identifying the genetic variability among coffee genotypes, especially the anatomical traits. In addition, these traits were effective in the early identification of genotypes, as occurred with Hybrid 12 and Hybrid 15, which have important traits, with a higher genetic weight (heritability) in the phenotype to compose future crossing processes for selecting drought-tolerant genotypes.

\section{Conclusions}

There is genetic divergence among the 15 studied Coffea canephora genotypes.

The phenotypic variation of the evaluated traits occurred predominantly due to genetic causes.

Genotype BRS 3213 has great genetic dissimilarity and constituted groups isolated from the other genotypes.

Stomatal density is the most efficient trait to explain the dissimilarity between genotypes.
Hybrid 12 and Hybrid 15 have leaf anatomical traits with a higher potential for drought tolerance.

\section{Acknowledgments}

The authors would like to thank the Consórcio Pesquisa Café for financial support and the Brazilian Federal Agency for Support and Evaluation of Graduate Education (Coordination for the Improvement of Higher Education Personnel-CAPES) for granting the scholarship.

\section{References}

Alvares, C. A., Stape, J. L., Sentelhas, P. C., Gonçalves, J. L. de M., \& Sparovek, G. (2013). Köppen's climate classification mapforBrazil.MeteorologischeZeitschrift, 22(6), 711-728. doi: 10.1127/0941-2948/ 2013/0507

Azevedo, A. M., Andrade, V. C., Jr., Oliveira, C. M., Fernandes, J. S. C., Pedrosa, C. E., Dornas, M. F., \& Castro, B. M. C. C. (2013). Seleção de genótipos de alface para cultivo protegido: divergência genética e importância de caracteres. Horticultura Brasileira, 31(2), 260-265. doi: 10.1590/ S0102-05362013000200014

Azevedo, A. M., Andrade, V. C., Jr., Pedrosa, C. E., Figueiredo, J. A., Viana, D. J. S., Lemos, V. T., \& Neiva, I. P. (2015). Divergência genética e importância de caracteres em genótipos de batata-doce visando a produção de silagem. Revista Brasileira de Ciências Agrárias, 10(3), 479-484. doi: 10.5039/agraria.v10i3a5165 
Barros, R. S., Maestri, M., Vieira, M., \&Braga, L. J., F. (1973). Determinação de área de folhas do café (Coffea arábica L. cv. 'Bourbon Amarelo'). Revista Ceres, 20(107), 44-52.

Batista, K. D., Araújo, W. L., Antunes, W. C., Cavatte, P. C., Moraes, G. A. B. K., Martins, S. C. V., \& DaMatta, F. M. (2012). Photosynthetic limitations in coffee plants are chiefly governed by diffusive factors. Trees, 26(1), 459-468. doi: 10.1007/s004 68-011-0606-2

Batista, L. A., Guimaraes, R. J., Pereira, F. J., Carvalho, G. R., \& Castro, E. M. (2010). Leaf anatomy and water potential in the coffee cultivars tolerance to water stress. Revista Ciência Agronômica, 41(3), 475-481. doi: 10.1590/S1806-66902010000300022

Blum, A. (2005). Drought resistance, wateruse efficiency, and yield potential are they compatible, dissonant, or mutually exclusive?. Australian Journal of Agricultural Research, 56(11), 1159-1168. doi: 10.1071/AR05069

Brinate, S. V. B., Rodrigues, W. N., Martins, L. D., Colodetti, T. V., Tomaz, M. A., \& Amaral, J. F. T. (2015). Applicability of the method of linear dimensions to estimate leaf area in improved genotypes of Coffea Arabica and Coffea canephora. American Journal of Plant Sciences, 6(5), 651-658. doi: 10. 4236ajps.2015.65070

Bunn, C., Laderach, P., Rivera, O. O., \& Kirschke, D. (2015). A bitter cup: climate change profile of global production of Arabica and Robusta coffee. Climatic Change, 129(1-2), 89-101. doi: 10.1007/s10584014-1306-x

Carvalho, F. G., Sera, G. H., Andreazi, E., Sera, T., Fonseca, I. C. de B., Carducci, F. C.,...
Costa, K. C. (2017) Tolerância ao déficit hídrico em mudas de genótipos de café portadores de genes de diferentes espécies. Coffee Science, 12(2), 156-163. doi: 10.25186/cs.v12i2.1175

Castanheira, D. T., Rezende, T. T., Baliza, D. P., Guedes, J. M., Carvalho, S. P., Guimarães, R. J., \& Viana, M. T. R. (2016). Potential use of anatomical and physiological characteristics in the selection of coffee progenies. Coffee Science, 11(3), 375386. doi: 10.25186/cs.v11i3.1105

Castro, E. M. de, Pereira, F. J., \& Paiva, R. (2009). Histologia vegetal: estrutura e função de órgãos vegetativos. Lavras: UFLA.

Covre, A. M., Canal, L., Partelli, F. L., Alexandre, R. S., Ferreira, A., \& Vieira, H. D. (2016). Development of clonal seedlings of promising conilon coffee (Coffea canephora) genotypes. Australian Journal of Crop Science, 10(3), 385-392. doi: 10.21475/ajcs.2016.10.03.p7235

Craparo, A. C. W., Van Asten, P. J. A., Läderach, P., Jassogne, L. T. P., \& Grab, S. W. (2015). Coffea arabica yields decline in Tanzania due to climate change: global implications. Agricultural and Forest Meteorology, 207(1), 1-10. doi: 10.1016/j. agrformet.2015.03.005

Cruz, C. D. (2016). Genes Software - extended and integrated with the $\mathrm{R}$, Matlab and Selegen. Acta Scientiarum Agronomy, 38(4), 547-552. doi:10.4025/actasciagron. v38i4.32629

Cruz, C. D., \& Regazzi, A. J. (1997). Modelos biométricos aplicados ao melhoramento genético (2a ed.). Viçosa, MG: UFV.

Damatta, F. M., Avila, R. T., Cardoso, A. A., Martins, S. C. V., \& Ramalho, J. C. 
(2018). Physiological and agronomic performance of the coffee crop in the context of climate change and global warming: a review. Journal of Agricultural and Food Chemistry, 66(21), 5264-5274. doi: 10.1021/acs.jafc.7b04537

Dubberstein, D., Partelli, F. L., Guilhen, J. H. S., Rodrigues, W. P., Ramalho, J. C., \& RibeiroBarros, A. I. (2021). Biometric traits as a tool for the identification and breeding of Coffea canephora genotypes. Genetics and Molecular Research, 19(2), gmr18541. doi: 10.4238/gmr18541

Espindula, M. C., Partelli, F. L., Dias, J. R. M., Marcolan, A. L., Teixeira, A. L., \& Fernandes, S. R. (2015). Condução de cafeeiros Coffea canephora. In A. Marcolan, \& M. C. Espindula, Café na Amazônia (cap. 10, pp. 219-236). Brasília: EMBRAPA.

Espindula, M. C., Teixeira, A. L., Rocha, R. B., Ramalho, A. R., Vieira, J. R., Jr., Alves, E. A.,... Fernandes, C. F. (2019). Novas cultivares de cafeeiros Coffea canephora para a Amazônia Ocidental Brasileira - principais características. (Comunicado Técnico). Porto Velho: EMBRAPA Rondônia.

Ferreira, R. T., Viana, A. P., Silva, F. H. L., Santos, E. A., \& Santos, J. O. (2016). Intrapopulation recurrent selection in sour passion fruit by mixed models. Revista Brasileira de Fruticultura, 38(1), 158-166. doi: 10.1590/ 0100-2945-260/14

Freire, L. P., Marraccini, P., Rodrigues, G. C., \& Andrade, A. C. (2013). Análise da expressão do gene da manose 6 fosfato redutase em cafeeiros submetidos ao déficit hídrico no campo. Coffee Science, 8(1), 17-23.
Gama, T. C. P. da, Sales, J. C., Jr., Castanheira, D. T., Silveira, H. R. de O., \& Azevedo, H. P. A. de. (2017). Anatomy and physiology of leaf coffee plants in different fertilizing levels. Coffee Science, 12(1), 42-48. doi: 10.25186/cs.v12i1.1195

Giles, J. A. D., Ferreira, A. D., Partelli, F. L., Aoyama, E. M., Ramalho, J. C., Ferreira, A., \& Falqueto, A. R. (2019). Divergence and genetic parameters between coffea sp. genotypes based in foliar morphoanatomical traits. Scientia Horticulturae, 245(1), 231-236. doi: 10.1016/j.scienta. 2018.09.038

Intergovernmental Panel on Climate Change (2014). Climate change 2014: regional aspects - central and South American. Geneva: IPCC. Retrieved from https:// www.ipcc.ch/pdf/assessment-report/ar5/ wg2/ WGIIAR5-Chap27_FINAL.pdf

International Coffee Organization (2019). Coffee Development Report 2019: growing for prosperity. Londres: ICO. Retrieved from https://www.http://www. internationalcoffeecouncil.org/eng/ coffee-development-report.php

Instituto Nacional de Meteorologia (2019). Estação Meteorológica de Observação de Superfície Automática. Retrieved from http://www.inmet.gov.br

Locatelli, G., Pio, R., Bisi, R. B., Souza, F. B. M. de, Viana, M. T. R., \& Farias, D. H. (2019). Leaf anatomy of apple trees during seasonal periods under subtropical conditions. Hortscience, 54(11), 1887-1895. doi: 10.21273/HORTSCI14205-19

Martins, M. Q., Rodrigues, W. P., Fortunato, A. S., Leitão, A. E., Rodrigues, A. P., Pais, I. P.,... Ramalho, J. C. (2016). Protective response 
mechanisms to heat stress in interaction with high $\left[\mathrm{CO}_{2}\right]$ conditions in Coffea spp. Frontiers in Plant Science, 7(1), 947. doi: 10.3389/fpls.2016.00947

Mazzafera, P. I., \& Carvalho, A. (1987). Produção e tolerância à seca de cafeeiros. Bragantia, 46(2), 403-415.

Medina-Filho, H. P., Carvalho, A., \& Medina, D. M. (1977). Germoplasma de Coffea racemosa e seu potencial no melhoramento do cafeeiro. Bragantia, 36(1), 43-46.

Melo, E. F., Fernandes-Brum, C. N., Pereira, F. J., Castro, E. M., \& Chalfun, A., Jr. (2014). Anatomic and physiological modifications in seedlings of Coffea arabica cultivar siriema under drought conditions. Ciência e Agrotecnologia, 38(1), 25-33. doi: 10.15 90/S1413-70542014000100003

Menezes-Silva, P. E., Sanglard, L. M. V. P., Ávila, R. T., Morais, L. E., Martins, S. C. V., Nobres, P.,... DaMatta, F. M. (2017). Photosynthetic and metabolic acclimation to repeated drought events play key roles in drought tolerance in coffee. Journal of Experimental Botany, 68(15), 4309-4322. doi: 10.1093/jxb/erx211

Nascimento, W. M. O., Gurgel, F. L., Bhering, L. L., \& Ribeiro, O. D. (2014). Pré-melhoramento do camucamuzeiro: estudo de parâmetros genéticos e dissimilaridade. Revista Ceres, 61(4), 538-543. doi: 10.1590/0034737X201461040013

Novais, R. F., Neves, J. C. L., \& Barros, N. F. (1991). Ensaio em ambiente controlado. In A. J. Oliveira, W. E. Garrido, J. D. Araújo, \& S. Lourenço (Coord.), Métodos de pesquisa em fertilidade do solo (pp. 189255). Brasília: EMBRAPA SEA.
Oliveira, I., Meyerb, A., Afonso, S., \& Gonçalves, B. (2018). Compared leaf anatomy and water relations of commercial and traditional Prunus dulcis (Mill.) cultivars under rain- fed conditions. Scientia Horticulturae, 229(1), 226-232. doi: 10.10 16/j.scienta.2017.11.015

Oliveira, N. S., Carvalho, J. L. S., Fo., Silva, D. O., Pastoriza, R. J. G., Melo, R. A., Silva, J. W., \& Menezes, D. (2015). Seleção e parâmetros genéticos de progênies de coentro tolerantes ao calor. Horticultura Brasileira, 33(3), 319-323. doi: 10.1590/ S0102-053620150000300007

Partelli, F. L., Vieira, H. D., Detmann, E., \& Campostrini. (2006). Estimativa da área foliar do cafeeiro conilon a partir do comprimento da folha. Revista Ceres, 53(306), 204-210.

Queiroz-Voltan, R. B., Nardin, C. F., Fazuoli, L. C., \& Braghini, M. T. (2014). Caracterização da anatomia foliar de cafeeiros arábica em diferentes períodos sazonais. Biotemas, 27(4), 1-10. doi: 10.5007/2175-7925.20 $14 \mathrm{v} 27 \mathrm{n} 4 \mathrm{p} 1$

Ramalho, A. R., Rocha, R. B., Veneziano, W., \& Santos, M. M. dos. (2014). Cultivar de cafeeiro Conilon BRS Ouro Preto - características agronômicas e agroindustriais. (Comunicado Técnico, 396). Porto Velho: EMBRAPA Rondônia.

Rocha, R. B., Muro-Abad, J. I., Araujo, E. F., \& Cruz, C. D. (2005). Avaliação do método centroide para estudo de adaptabilidade ao ambiente de clones de Eucalyptus grandis. Ciência Florestal, 15(3), 255-266.

Rodrigues, W. N., Brinate, S. V. B., Martins, L. D., Colodetti, T. V., \& Tomaz, M. A. (2017). Genetic variability and expression of agro- 
morphological traits among genotypes of Coffea arabica being promoted by supplementary irrigation. Genetics and Molecular Research, 16(2), gmr16029563. doi: $10.4238 / g m r 16029563$

Rodrigues, W. P., Martins, M. Q., Fortunato, A. S., Rodrigues, A. P., Semedo, J. N., Simões-Costa, M. C.,... Ramalho, J. C. (2016b). Long-term elevated air $\left[\mathrm{CO}_{2}\right]$ strengthens photosynthetic functioning and mitigates the impact of supra-optimal temperatures in tropical Coffea arabica and C. canephora species. Global Change Biology Bioenergy, 22(1), 415-431. doi: 10.1111/gcb.13088

Rodrigues, W. P., Silva, J. R., Ferreira, L. S., Machado, J. A., Fo., Figueiredo, F. A. M. M. A., Ferraz, T. M.,... Campostrini, E. (2018). Stomatal and photochemical limitations of photosynthesis in coffee (Coffea spp.) plants subjected to elevated temperatures. Crop \& Pasture Science, 69(3), 317-325. doi: 10.1071/CP17044

Rodrigues, W. P., Vieira, H. D., Teodoro, P. E., Partelli, F. L., \& Barbosa, D. H. S. G. (2016a). Assessment of genetic divergence among coffee genotypes by Ward-MLM procedure in association with mixed models. Genetics and MolecularResearch, 15(2), 1-7. doi: 10.4238/gmr.15027889

Sack, L., \& Buckley, T. N. (2016). The development basis of stomatal density and flux. Plant Physiology, 171(4), 23582363. doi: $10.1104 / p p .16 .00476$

Schmildt, E. R., Amaral, J. A. T., Santos, J. S., \& Schmildt, O. (2015). Allometric model for estimating leaf area in clonal varieties of coffee (Coffea canephora). Revista Ciência Agronômica, 46(4), 740-748. doi: 10.5935/1806-6690.20150061
Scotti-Campos, P., Paisa, I. P., RibeiroBarros, A. I., Martins, L. D., Tomaz, M. A., Rodrigues, W. P.,... Ramalho, J. (2019). Lipid profile adjustments may contribute to warming acclimation and to heat impact mitigation by elevated $\left[\mathrm{CO}_{2}\right]$ in Coffea spp. Environmental and Experimental Botany, 167(1), 103856. doi: 10.1016/j. envexpbot.2019.103856

Starling, L. C. T., Martins, L. D., Rodrigues, W. N., Reinicke, T. M., Colodetti, T. V., Amaral, J. F. T.,... Espindula, M. C. (2019). Genetic diversity in nutritional parameters in response to drought of Coffea canephora cultivated in Rondonia state, Brazil. Genetics and Molecular Research, 18(2), gmr18300. doi: 10.4238/gmr18300

Teixeira, A. L., Souza, F. de F., Rocha, R. B., Vieira, J. R., Jr., Torres, J. D., Rodrigues, K. M.,... Lourenço, J. L. R. (2017). Performance of intraspecific hybrids(KouillouxRobusta) of Coffea canephora Pierre. African Journal of Agricultural Research, 12(35), 26752680. doi: 10.5897/AJAR2017.12446

Teixeira, A. L., Rocha, R. B., Espindula, M. C., Ramalho, A. R., Vieira, J. R., Jr., Alves, E.A.,... Fernandes, C. F. (2020). Amazonian robustas - new Coffea canephora coffee cultivars for the Western Brazilian Amazon. Crop Breeding and Applied Biotechnology, 20(3), e323420318. doi: 10.1590/1984-70332020v20n3c53

Viana, M. T. R., Gama, T. C. P. da, Guedes, J. M., Guimarães, R. J., Azevedo, H. P. A. de, Castanheira, D. T., \& Naves, V. L. (2018b). Genetic divergence between coffee genotypes resistant to rust based on anatomical features. Revista de Ciências Agroveterinárias, 17(4), 547-555. doi: 10. $5965 / 223811711732018547$ 